\title{
Subsídios para o estudo histopatológico das lesões
} ungueais*

\section{Base for the histopathological study of nail lesions*}

Geraldo Magela Magalhães ${ }^{1}$
Isabel Cristina Brasil Succi
Maria Auxiliadora Jeunon Sousa ${ }^{3}$

\begin{abstract}
Resumo: FundAmENTOS - Os autores apresentam ampla revisão sobre os fundamentos da biópsia da unidade ungueal, fornecendo bases teóricas sobre anatomia, histologia e histopatologia. Abordam, detalhadamente, as indicações e os objetivos da biópsia da unidade ungueal e as várias técnicas disponíveis.

OBJETIVos - Definir os locais adequados da biópsia do aparelho ungueal para as diferentes doenças da unha, comparar duas formas de amaciamento da lâmina ungueal, uma utilizando $\mathrm{KOH}$ a $20 \%$, outra, solução aquosa de Tween 40 a 10\%, e estabelecer uma rotina para o processamento do material de biópsia.

MATERIAL E MÉTODOS - 0 grupo de estudo constou de 11 pacientes com doença ungueal, que procuraram 0 ambulatório de Dermatologia do HUPE/UERJ para esclarecimento diagnóstico. Foi realizado o total de 12 biópsias.

RESULTADOS - Não houve diferença na dificuldade técnica, em incluir ou cortar o material, consoante ao método de amaciamento utilizado, nem prejuízo citológico ou histológico ao exame histopatológico.

CONCLUSÕES - Os autores concluíram que biópsia ungueal é procedimento seguro e eficaz para esclarecer 0 diagnóstico das doenças ungueais quando o exame clínico ou outras técnicas falharam. Também é importante, para quem deseja realizar o procedimento, o conhecimento adequado da anatomia dessa região.

Palavras-chave: biópsia; doenças da unha; patologia.
\end{abstract}

Summary: BACKGROUND - In this paper a broad review of nail biopsy is presented, emphasizing its anatomy, embryology, histology and histopathology. The indication and purpose of nail biopsy as well as the techniques available are reviewed in detail.

OBJECTIVE - Define the appropriate site for nail biopsy according to nail disorder, compare two different methods of nail specimen softening: soaking in $20 \%$ potassium hydroxide and in $10 \%$ aqueous solution of Tween 40 and establish a routine for the nail biopsy procedure.

MATERIAL AND METHODS - Our group studied eleven patients with nail disease who presented at the Dermatology Department in Pedro Ernesto University Hospital for a definite diagnosis. Twelve biopsi es were performed.

RESULTS - There were no differences in the softness achieved with the two methods and none harmed the cytologic and histologic analysis.

ConcLusions - The authors concluded that nail biopsy is a safe and useful procedure for nail diseases when clinical and laboratory methods fail to reach a diagnosis. A complete and thorough understanding of the nail unit anatomy is necessary to perform the procedure.

Key-words: biopsy; nail diseases; pathology.

Recebido em 30.03.2001. / Received in March, $30^{\text {th }}$ of 2001

Aprovado pelo Conselho Consultivo e aceito para publicação em 23.08.2002. / Approved by the Consultive Council and accepted for publication in August, $23^{\text {th }}$ of 2002.

* Trabalho realizado no Serviço de Dermatologia da Uerj - Hospital UniversitárioPedro Ernesto como Monografia Final de Curso / Work done at the Dermatology Service of the Uerj -

Hospital Pedro Ernesto, as final monograph of course

Especialista em Dermatologia pela SBD e aluno do Curso de Pós-Graduação em Dermatologia da UFRJ - Nível Doutorado. / Specialist in Dermatology from the SBD / Ph.D. Student of Dermatology, UFRJ.

Chefe do Serviço de Dermatologia da UERJ. / Head of Dermatology Service, UERJ

Responsável pelo Setor de Dermatopatologia da UERJ / Head of the Dermatopathology Dept., UERJ

(C)2003 by Anais Brasileiros de Dermatologia 


\section{INTRODUÇÃO}

Os dermatologistas não hesitam em biopsiar a pele para confirmar diagnóstico ou excluir malignidade. O comportamento em relação à biópsia da unha é, entretanto, completamente diferente. As dúvidas e os medos são muitos. Quais são as indicações? Qual o local adequado da biópsia na unidade ungueal? Qual técnica é a mais segura e acessível, e menos traumática? Haverá seqüela definitiva? Como processar o material? Os autores tentaram buscar respostas para essas perguntas.

\section{Unidade Ungueal}

\section{Anatomia Funcional}

A unha (ou úngüis; úngües no plural) é anexo cutâneo que se superpõe à face dorsal das falanges distais. As unhas protegem as sensíveis extremidades digitais, prestam-se à função de arranhar, crescendo cerca de dois a 4,5mm por mês. ${ }^{1}$

Filogeneticamente, as unhas evoluíram das garras das aves e répteis e dos cascos dos mamíferos inferiores. Elas protegem a falange distal de impactos traumáticos, têm função de pinça, participam da função discriminativa e são usadas para arranhar. Não se pode esquecer também sua função cosmética. ${ }^{2}$

Os componentes da unidade ungueal são basicamente seis: ${ }^{2}$

- a matriz ungueal, que é a porção geradora;

- a lâmina ungueal, produto da ceratinização da matriz;

- o sistema cuticular, englobando o eponíquio ou cutícula visível, derivada da prega ungueal proximal, e o hiponíquio, derivado do epitélio do leito ungueal;

- a porção de suporte representada pelo leito ungueal e falange óssea;

- a porção de ancoragem representada pelo mesênquima especializado que existe proximalmente entre a falange e a matriz e distalmente entre a falange e a polpa digital lateral e distal;

- o arcabouço composto pelas pregas ungueais: proximal, lateral e distal.

A configuração da lâmina ungueal é definida por delicado balanço entre alguns parâmetros: forma, convexidade, contorno da extremidade distal, espessura e horizontalidade da silhueta da lâmina. ${ }^{2}$ Os primeiros quatro parâmetros são responsáveis pela morfologia da lâmina, e o quinto por sua posição.

O suprimento sangüíneo do leito e da matriz é composto por rica rede derivada das artérias digitais. Existem dois arcos arteriais principais (proximal e distal) formados por anastomoses dos ramos das artérias digitais e várias anastomoses arteriovenosas no leito ungueal (corpos glômicos), as quais se relacionam com a regulação térmica. ${ }^{3}$

A inervação faz-se por ramos dos nervos digitais. A unidade ungueal do quinto e da metade medial do quarto dedos recebem inervação sensitiva pelo ulnar. O restante se faz por meio do mediano. ${ }^{3}$

\section{INTRODUCTION}

Although dermatologists do not hesitate to perform a skin biopsy to confirm diagnosis or exclude the possibility of malignancy, their behavior in relation to nail biopsy is completely different. The doubts and fears are many. What are the indications? Which is the appropriate site for biopsy in the ungual unit? Which technique is the safest, most accessible and least traumatic? Will there be a definitive sequel? How does one process the material? In this work, the authors attempted to provide answers for these questions.

\section{Ungual Unit}

\section{Functional Anatomy}

The nail (or unguis; pl. ungues) is a cutaneous annex that covers the dorsal face of the fingers and toes. The nails protect the sensitive digital extremities and serve the function of scratching, growing about 2 to $4.5 \mathrm{~mm}$ each month. ${ }^{1}$

Philogenetically, the nails evolved from the claws of birds and reptiles and the shells of inferior mammals - sic. They protect the distal phalange from traumatic impact; they also function as tweezers; participate in the sensory function; and are used to scratch. Also, one cannot forget their cosmetic function in humans. ${ }^{2}$

There are basically six components in the ungual unit: $^{2}$

- the nail matrix, which is the root;

- the nail plate, product of the keratinization of the matrix; - the cuticula system, including the eponychium or visible cuticle, derived from the proximal nail fold, and the hyponychium, derived from the epithelium of the nail bed;

- the support portion represented by the nail bed and phalangeal bone;

- the anchorage portion represented by the specialized mesenchyma that is proximal between the phalange and matrix and distal between the phalange and the lateral and distal digital pulp;

- the mantle composed by the nail folds: proximal, lateral and distal;

The configuration of the nail plate is defined by a delicate balance between some parameters: form, convexity, outline of the distal extremity, thickness and the sidewalls of the plate. ${ }^{2}$ The first four parameters are responsible for the morphology of the plate and the latter for its position.

The blood supply of the bed and matrix is composed of a rich network of digital arteries. There are two main arterial arcades (proximal and distal) formed by anastomoses of the branches of the digital arteries, together with several arteriovenous anastomoses in the nail bed (glomus body), which are related to the thermal regulation. ${ }^{3}$

Branches of the digital nerves affect the innervation. The ungual unit of the fifth and medial half of the fourth fingers receives sensitive innervation from the ulnar nerve. The remainder is made through the median nerve. ${ }^{3}$ 


\section{Histopatologia}

Griffin em $1977,{ }^{4}$ Omura em $1985^{5}$ e Jerasutus em $1997^{6}$ descreveram, com detalhes, a histopatologia das doenças ungueais.

O conhecimento da histopatologia das doenças da unha é muito mais limitado do que o das doenças da pele não só porque quantidade menor de biópsias é realizada, como também por suas estruturas anatômicas distintas e mais complexas do que a da pele.

O maior problema encontrado é a possibilidade de perda da orientação adequada à inclusão do material. Daí a importância de se marcarem os fragmentos obtidos, orientando o posicionamento para correta inclusão.

Num corte longitudinal encontram-se: a lâmina ungueal, a prega ungueal proximal, a matriz, o leito e o hiponíquio.

A prega ungueal proximal apresenta epitélio dorsal e ventral. A superfície dorsal contém glândulas sudoríparas, mas é desprovida de unidades pilossebáceas. A epiderme apresenta as quatro camadas habituais, e a relação cone/papila está preservada. O epitélio ventral é cornificado, também com as quatro camadas, porém é mais fino, retificado, sem quaisquer apêndices epidérmicos. A camada córnea originada desse epitélio constitui a cutícula, a qual, funcionando como selo, previne a entrada de bactérias e de umidade.

A matriz ungueal é um epitélio germinativo, espesso, sem interposição de camada granulosa, com cones largos que se voltam para baixo e para a porção proximal.

À medida que suas células progridem para as camadas superiores, o citoplasma torna-se intensamente eosinofílico e o núcleo torna-se picnótico, até desaparecer por completo e as células da lâmina ungueal se transformarem em onicócitos. A lúnula, parte visível da matriz, apresenta ainda as mesmas características, sendo zona queratógena.

Na matriz, os melanócitos estão presentes, mas são pobremente desenvolvidos e pouco numerosos. Apresentam

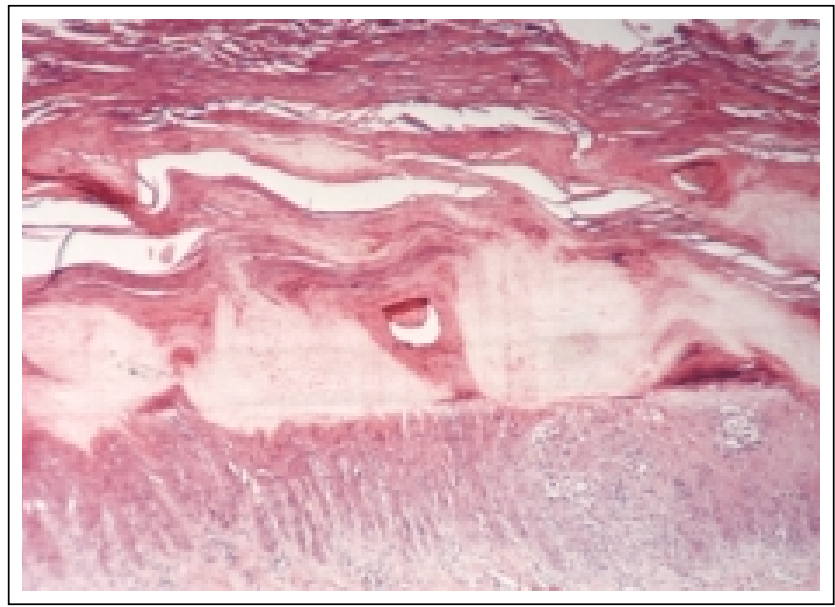

Figura 1: H\&E - Traquioníquia: perda da coesão dos onicócitos na porção superior da lâmina ungueal

Figure 1: H\&E - Trachyonychia: loss of cohesion of the onychocytes in the superior portion of the nail plate

\section{Histopa thology}

Griffin in 1977, ${ }^{4}$ Omura in $1985^{5}$ and Jerasutus in $1997^{6}$ provided detailed descriptions of the ungual diseases.

Knowledge of the histopathology of nail diseases is much more limited than that of cutaneous diseases, not only because fewer biopsies have been performed, but due to the different and more complex anatomical structures when compared to those of the skin.

The greatest obstacle is the possibility of losing correct orientation in the inclusion of material. Hence the importance of marking the specimens obtained, to guide their positioning for correct inclusion.

In a longitudinal section one finds the nail plate, proximal nail fold, nail matrix, nail bed and hyponychium.

The proximal nail fold presents dorsal and ventral epithelium. The dorsal surface contains sudoriparous glands, but has no pilosebaceous units. The epidermis presents the four usual layers, and the cone/papilla relationship is preserved. The ventral epithelium is cornified, as are the four layers, however it is finer, rectified and without any epidermal appendixes. The horny layer originating from this epithelium constitutes the cuticle, which functions as a seal to prevent the entry of bacteria and humidity.

The nail matrix is a thick germinative epithelium, without interposition of a granular layer, with wide cones located downward toward the proximal portion.

As their cells progress into the superior layers, the cytoplasm becomes intensely eosinophilic and their nuclei become picnotic, until disappearing entirely and the cells of the nail bed turn into onychocytes. The lunula, the visible part of the matrix, continues to show the same characteristics and forms the keratogenous zone.

Melanocytes are present in the matrix, but are few and poorly developed. They present both basal and suprabasal location, and this could be a consequence of the

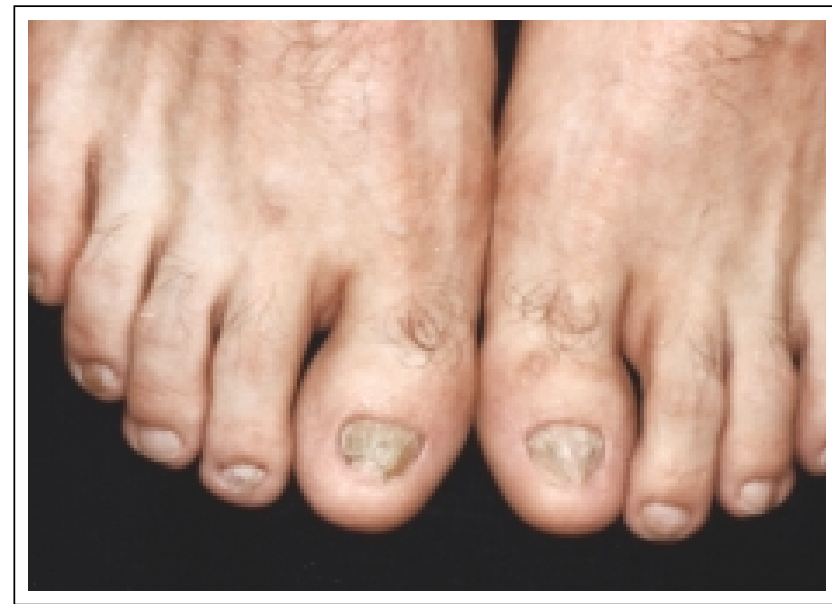

Figura 2: Pterígio ungueal dorsal, suspeita clínica de líquen plano

Figure 2: Pterygium unguis, clinical suspicion of lichen planus 


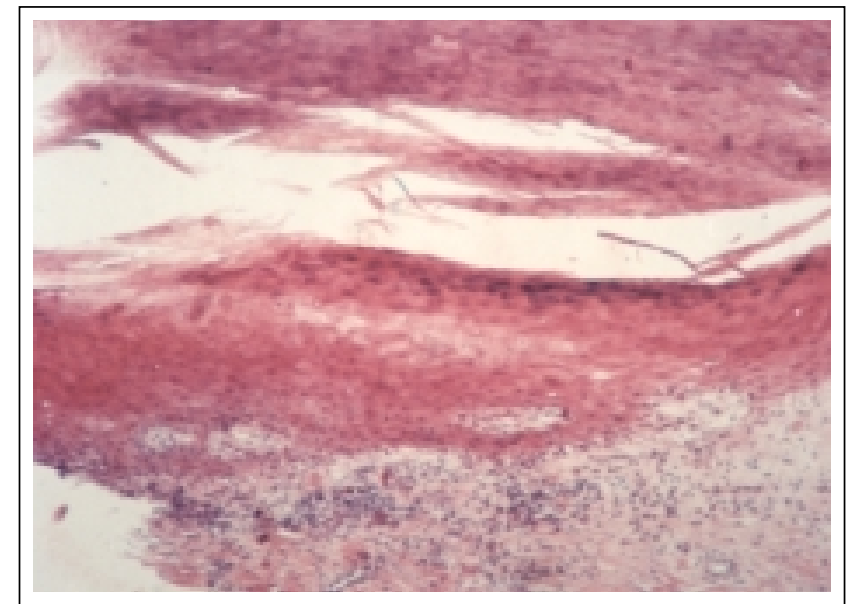

Figura 3: H\&E - Líquen plano ungueal: observam-se hipergranulose, hiperplasia e liquenificação da camada basal do leito ungueal, borrada por linfócitos. Mais distalmente encontra-se tecido de granulação próprio da fase inicial do pterígio.

Figure 3: H\&E - Ungual lichen planus: hypergranulosis, hyperplasia and lichenification of the basal layer of the nail bed can be observed, although blurred by lymphocytes. More distally there

is granulation tissue characteristic of the initial phase of pterygium unguis.

localização tanto basal quanto suprabasal, e isso pode ser conseqüência da expressão de moléculas de adesão no epitélio ungueal. Nesta última localização, as integrinas $\alpha 3 \mathrm{e}$ $\beta 1$, que provavelmente regulam a adesão de melanócitoqueratinócito, são expressas tanto na camada basal quanto na suprabasal. ${ }^{7}$ A densidade é menor na matriz proximal, talvez pela proteção à exposição aos raios ultravioletas dada pela prega proximal. Células de Langerhans e de Merkel também têm sido identificadas nessa localização. A matriz é dividida em três zonas: a proximal, a intermediária e a distal, fazendo parte desta última, a lúnula.

A lâmina ungueal é constituída por células cornificadas, de arranjo lamelar, que se coram fracamente pela eosina e fortemente pelas colorações acidorresistentes. Sua origem persiste controversa. Zaias, em $1968,{ }^{8}$ pesquisando a formação da lâmina ungueal em primatas por meio de estudo autoradiográfico, concluiu ter a lâmina ungueal origem exclusiva na matriz. Johnson, em 1991, ${ }^{9}$ afirmou ser a porção ventral da lâmina, cerca de $20 \%$ de sua espessura, produzida pelo leito.

O epitélio do leito ungueal repousa abaixo da lâmina ungueal e é limitado distalmente pelo hiponíquio e proximalmente pela matriz. Ele não apresenta células granulosas, é relativamente fino e, nos cortes sagitais, contém poucas células paraceratóticas. Nos cortes transversais, apresenta-se firmemente aderido à derme subjacente por longos e estreitos cones epidérmicos, interpostos às papilas dérmicas.

O hiponíquio ceratiniza como a pele volar, apresentando camada de células granulosas e camada córnea espessa e compacta.

A derme é altamente vascular e suprida por artérias digitais. Existem numerosos corpos glômicos que, funcio-

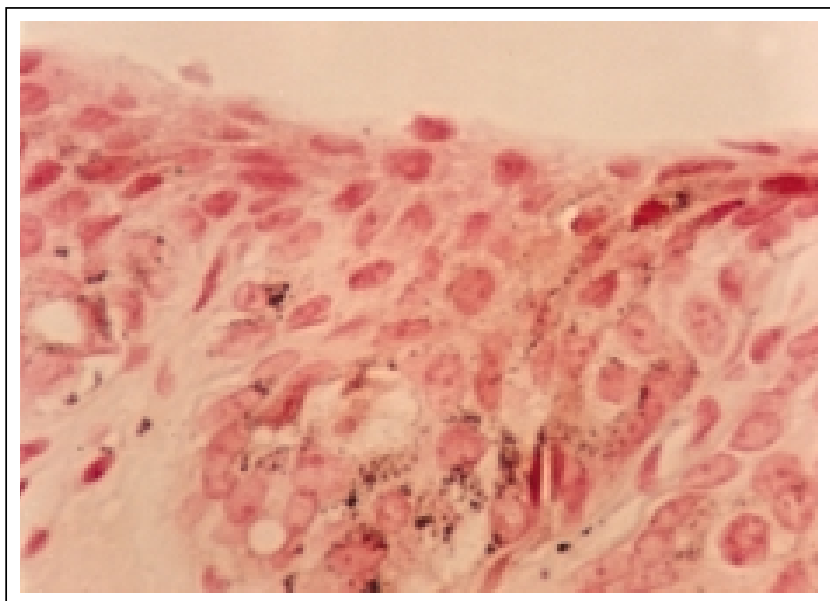

Figura 4: Fontana Masson - Hiperplasia melanocítica benigna: acima da junção observa-se melanócito de núcleo pequeno, citoplasma amplo e pálido. A melanina, corada em castanho, é vista no citoplasma de queratinócitos e nos dendritos melanocíticos que, às vezes, atingem a porção mais superficial.

Figure 4: Masson-Fontana - Benign melanocytic hyperplasia: above the junction one can observe small nucleus and ample and pale cytoplasm melanocytes. The melanin, stained brown, is seen in the cytoplasm of the keratinocytes and in the melanocytic dendritic process, which sometimes involves the most superficial portion.

expression of adhesion molecules in the ungual epithelium. In the latter location, the integrins $\alpha 3$ and $\beta 1$, which probably regulate the melanocyte-keratinocyte adhesion, are expressed in the basal and suprabasal layer. ${ }^{7}$ The proximal matrix is less dense, perhaps due to the protection against exposure to ultraviolet rays provided by the proximal fold. Langerhan and Merkel's cells have also been identified in this location. The matrix is divided into three zones: the proximal, intermediate and distal, of which the lunula comprises part of the latter.

The nail plate is constituted of cornified cells in a lamellar arrangement that is colored faintly by eosin and strongly by the acid resistant dyes. Their origin continues to be controversial. Zaias, in 1968, ${ }^{8}$ researching the formation of the nail plate in primates through auto-radiographic study, concluded that the nail plate has its origin exclusively in the matrix. Johnson $(1991)^{9}$ stated that the ventral portion of the plate, about $20 \%$ of its thickness, is produced by the nail bed.

The epithelium of the nail bed rests below the nail plate and is distally limited by the hyponychium and proximally by the matrix. It does not present granular cells and is relatively thin. In the sagittal section it contains few parakeratotic cells. In the traverse section, it is firmly adhered to the underlying dermis by long and narrow epidermal cones, interposed to the dermal papillae.

The hyponychium becomes keratinized like the volar skin, presenting a layer of granular cells and the horny layer is thickened and more compact.

The dermis is highly vascular and supplied by digital arteries. They are numerous glomic bodies that, working 
nando como shunts arteriovenosos, regulam a temperatura dos dedos. Troncos e terminações nervosas são também numerosos. A derme repousa diretamente sobre a falange distal, sem interposição de tecido celular subcutâneo.

\section{A Biópsia Ungueal}

\section{Considerações Gerais}

Stone, em $1978,{ }^{10}$ afirmou que a biópsia ungueal só se justificaria nos casos em que a possibilidade de malignidade estivesse presente. Naqueles com hipótese diagnóstica de psoríase ou líquen plano, por exemplo, seria preferível assumi-lo clinicamente.

Já outros autore ${ }^{11,12}$ consideram-na recurso diagnóstico seguro, de fácil execução e útil para várias doenças ungueais quando a rotina clínica e os métodos laboratoriais falham no esclarecimento diagnóstico. Trata-se de procedimento seguro que pode e deve ser realizado pelo dermatologista. ${ }^{11,12}$

São pré-requisitos para a realização da biópsia ungueal o conhecimento adequado da anatomia da unha, da anestesia e da hemostasia, e a presença de anormalidade ungueal na qual a histopatologia provê diagnóstico. ${ }^{12}$

A indicação e os métodos variam de acordo com o sítio e o tipo da doença na unidade ungueal. ${ }^{12}$

Os fragmentos obtidos das biópsias ungueais podem ser de difíceis orientação, processamento e interpretação. É importante manter contato direto com um dermatopatologista experiente. ${ }^{5,6,12}$

\section{Metódos e Indicações}

Biópsia Longitudinal de todos os Elementos da Unha

Inicialmente descrita por Zaias em $1967^{13}$ correspondendo à retirada de um fragmento longitudinal mediano. Nesse caso, obtêm-se informações de todos os elementos da unidade ungueal: prega ungueal proximal, matriz, leito e lâmina ungueal. $\mathrm{O}$ autor recomenda que a biópsia não exceda a $3 \mathrm{~mm}$ de largura na região da matriz, o que evitaria cicatriz definitiva.

Em 1980 Scher $^{14}$ descreve novamente, com detalhes, essa técnica, sugerindo algumas modificações e ampliando o campo de ação não só diagnóstico, como também terapêutico, para ablação de lesões neoplásicas e correção de onicocriptose.

As principais indicações englobam doenças da matriz ungueal ou de toda a unidade ungueal: tumores da matriz, melanoníquia estriada e distrofias ungueais que envolvam extensamente a lâmina ungueal. Eventualmente, é também indicada para o diagnóstico de psoríase e de líquen plano, quando toda a unidade ungueal se encontrar envolvida. ${ }^{12}$

\section{Biópsia Excisional e Incisional}

Podem ser realizadas no leito ou na matriz.

No leito, as excisões devem ser fusiformes longitudinais, quando possível, e limitadas à largura de $3 \mathrm{~mm}$. É sugerido que a sutura traz melhores resultados estéticos. ${ }^{15}$ as arteriovenous shunts, regulate the temperature of the fingers. Trunks and nerve endings are also numerous. The dermis rests directly on the distal phalange, without interposition of subcutaneous cellular tissue.

\section{Nail Biopsy}

General Considerations

Stone, in $1978,^{10}$ stated that nail biopsy is only justified in cases in which there is a possibility of malignanc, while in those with a diagnostic hypothesis of psoriasis or lichen planus, for instance, it would be preferable to manage the picture clinically.

Other authors ${ }^{11,12}$ consider nail biopsy to be a safe diagnostic resource that is easy to perform and useful for several ungual diseases, when the clinical routine and laboratory methods fail to reach the diagnosis. It is a safe procedure that can and should be performed by a dermatologist. ${ }^{11,12}$

The prerequisites for performing ungual biopsy are appropriate knowledge of the nail anatomy, anesthesia and hemostasia and the presence of a histopathologicaly identifiable diagnosis. ${ }^{12}$

The indication and methods vary according to the site and type of disease in the ungual unit. ${ }^{12}$

Specimens obtained from nail biopsies can present difficult orientation, processing and interpretation. Thus it is important to maintain direct contact with an experienced dermatopathologist. ${ }^{5,6,12}$

\section{Methods and Indications}

Longitudinal Biopsy of all the Nail Elements

Initially described by Zaias in $1967^{13}$ it corresponds to the removal of a median longitudinal fragment. In this case, information is obtained regarding all of the elements of the nail unit: proximal nail fold, matrix, bed and plate. The author recommends that the biopsy does not exceed $3 \mathrm{~mm}$ in width within the area of the matrix, so as to avoid a permanent scar.

In 1980, Scher ${ }^{14}$ once again provided a detailed description of this technique and suggested some modifications, broadening the field of action both in the diagnosis and therapeutics for ablation of neoplastic lesions and correction of onychrocryptosis.

The main indications include diseases of the matrix or the entire nail unit: tumors of the matrix, striated melanonychia and nail dystrophy with extensive involvement of the nail plate. Sometimes, it is also indicated for the diagnosis of psoriasis and lichen planus, when the whole ungual unit is involved. ${ }^{12}$

\section{Excision and Incision Biopsy}

These can be performed in the nail bed or matrix. In the bed, the excisions should be fusiform and longitudinal when possible and limited to a width of $3 \mathrm{~mm}$. Some argue that suture provides better aesthetic results. ${ }^{15}$ 
Figura 5: PAS - Hifas septadas regulares na porção inferior da lâmina ungueal e hiperceratose subungueal

$\mathrm{Na}$ matriz, a orientação do maior eixo do fuso deve acompanhar a forma crescente da lúnula. Atenção deve ser dada à espessura do fuso, que não deve ultrapassar $3 \mathrm{~mm} .{ }^{16}$

As indicações incluem: tumores e lesões vegetativas no leito ungueal; pigmentação inexplicada, onicólise e hiperceratose, alterações suspeitas de onicomicose ou de psoríase. Na matriz ungueal, pode-se utilizá-la para excluir malignidade em lesões de melanoníquia, diagnosticar tumores e distrofias. $^{12}$

\section{Biópsias por punch}

Scher, em 1978, ${ }^{11}$ descreveu detalhadamente a técnica para realizar biópsias das unhas por punch, demonstrando-a método simples, que permite melhorar a acurácia diagnóstica e o tratamento das doenças ungueais. Enfatizou a importância da possibilidade de descartar malignidade.

As indicações incluem doenças dos vários elementos da unidade ungueal: matriz, leito e pregas ungueais. ${ }^{12}$

Um dos inconvenientes dessa técnica é o fato de só poder ser estudado um dos elementos da unidade ungueal em cada biópsia.

Stone, em 1978, ${ }^{10}$ descreveu a biópsia da prega ungueal proximal utilizando punch de $2 \mathrm{~mm}$ em pacientes com paroníquia crônica, resistente à terapêutica, bem como o achado de corpos estranhos como agentes etiológicos.

Souza, em 1995, ${ }^{17}$ mostrou a utilidade da biópsia ungueal por punch como o principal método diagnóstico nos casos em que doenças, como psoríase e líquen plano, são exclusivas do aparelho ungueal.

Figura 6: H\&E - Psoríase ungueal: lâmina ungueal com perda da coesão dos onicócitos, encontrando-se de permeio abscessos e focos hemorrágicos, de cor alaranjada, sobre as áreas com ausência de granulosa. $O$ leito ungueal exibe sinais de liquenificação, com hipergranulose, hiperplasia e espongiose focal.

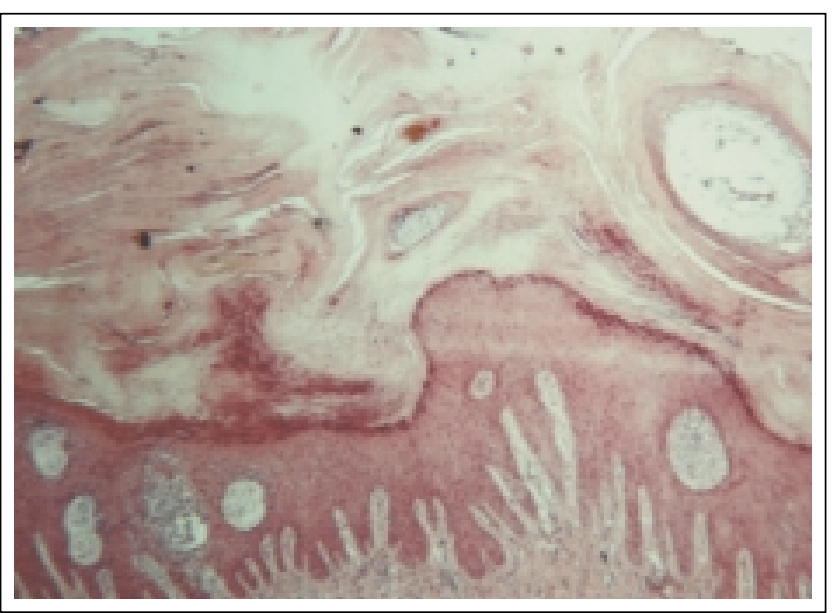

Figure 6 - H\&E - Ungual psoriasis: nail plate with loss of cohesion of the onychocytes, located among abscesses and hemorrhagic focuses, with an orange coloration, over areas with an absence of granulosa. The nail bed presents signs of lichenification with hypergranulosis, hyperplasia and focal spongiosis. 


\section{Outros Métodos}

Quando a lesão atinge o aparelho ungueal em suas pregas, outros métodos podem ser utilizados, como excisão em bloco, barbirese (shaving) ou excisão em crescente da prega ungueal. ${ }^{12}$

\section{Outras Considerações}

Elewski, em $1996,{ }^{18}$ reforçou a necessidade da avaliação histopatológica das unhas clinicamente suspeitas de onicomicose cujos exames micológicos diretos pelo $\mathrm{KOH}$ e culturas tenham sido negativos.

Blecher, em $1993,{ }^{19}$ utilizou, para cultura, material obtido com o uso de um motor de alta rotação. Observou que se tratava de um passo possível, no diagnóstico de infecção fúngica, entre a coleta tradicional de material da unha para exame micológico e a biópsia.

Machler, em 1998, ${ }^{20}$ utilizou fragmentos da lâmina ungueal para realizar exame histológico em casos com distrofia, concluindo tratar-se de técnica simples e efetiva no diagnóstico de onicomicose e psoríase, com o incoveniente de não identificar o fungo.

Grammer-West, em 1998, ${ }^{21}$ mostrou casos em que o diagnóstico de psoríase foi obtido por meio do exame histopatológico da lâmina ungueal avulsionada.

\section{Processamento do Material}

O processamento do material biopsiado envolve técnicas de amaciamento da lâmina ungueal, inclusão e colorações.

Alvarez, em 1967, ${ }^{22}$ descreveu técnica de processamento utilizando um método de inclusão em polietileno glicol piroxilina, no qual o amaciamento da lâmina ungueal era realizado pela fixação do material em ácido tricloroacético a $5 \%$ e formalina a $10 \%$.

O material mais utilizado para inclusão da biópsia é a parafina.

Lewin, em $1973,{ }^{23}$ descreveu o emprego de vários métodos de amaciamento da lâmina ungueal. Para as unhas de espessura normal, os métodos utilizando hidróxido de potássio associado ao ácido nítrico após fixação em formol ou tween 40 e a seguir formol eram igualmente eficazes. Para unhas espessas, a técnica preferida seria o Tween 40, embora a utilização de hidróxido de potássio também fosse efetiva.

Piérard, em 1994, ${ }^{24}$ utilizou, durante 24 horas, solução aquosa a $10 \%$ de Tween 40 , com bons resultados, no amaciamento de suas biópsias ungueais; a seguir adotava técnicas habituais de formalização e inclusão em parafina.

Em geral, as lâminas são coradas pela hematoxilinaeosina e PAS.

\section{PACIENTES E MÉTODOS}

Neste estudo, foram incluídos os pacientes que procuraram o ambulatório de Dermatologia do HUPE/UERJ, nos meses de outubro e novembro de 1999, para esclarecimento diagnóstico e conduta terapêutica de lesões ungueais.

\section{Other Methods}

When the lesion involves the folds of the nail apparatus, other methods can be used, such as block excision, shaving or crescent shaped excision of the nail fold. ${ }^{12}$

\section{Other Considerations}

Elewski, in 1996, ${ }^{18}$ stressed the need for a histopathological evaluation of nails with clinical suspicion of onychomycosis in which direct mycological exams for $\mathrm{KOH}$ and cultures were negative.

Blecher, in 1993, ${ }^{19}$ used a high rotation motor for collecting material for the cultures. It was observed that this was a feasible option for the diagnosis of fungal infection, midway between the traditional method for collection of material from the nail for mycological exam and the biopsy.

Machler, in 1998, ${ }^{20}$ used fragments of the nail plate to perform histological exam in cases with dystrophy, concluding that it is a simple and effective technique for the diagnosis of onychomycosis and psoriasis, without the inconvenience of having to identify the fungi.

Grammer-West, in 1998, ${ }^{21}$ described cases in which the diagnosis of psoriasis was obtained through histopathological exam of the nail plate.

\section{Processing the Material}

Processing the biopsy material involves techniques for softening the nail plate, inclusion and staining.

Alvarez, in 1967,22 described a method using inclusion in pyroxylin glycol polyethylene, in which the nail plate was softened by fixing in 5\% trichloroacetic acid and $10 \%$ formalin.

Paraffin is the most often used material for inclusion of the biopsy.

Lewin $(1973)^{23}$ described several techniques for softening the nail plate. For nails of normal thickness, the methods using potassium hydroxide associated with nitric acid after fixation in formol or Tween 40 followed by formol were equally effective. For thick nails, the preferable technique is Tween 40, although the use of potassium hydroxide is also effective.

Piérard, in 1994, ${ }^{24}$ used a $10 \%$ aqueous solution of Tween 40 for 24 hours with good results for the softening of their nail biopsies; followed by the usual techniques for formalization and inclusion in paraffin.

In general, the plates are stained with hematoxylin and eosin or PAS.

\section{PATIENTS AND METHODS}

The patients in this study are those who presented with lesions at the Dermatology Clinic of the University Hospital Pedro Ernesto (HUPE/UERJ), during October and November 1999, for diagnosis and therapeutic management 
Tabela 1: Resultados / Table 1: Results

\begin{tabular}{|c|c|c|c|c|c|c|c|}
\hline $\begin{array}{l}\text { Paciente } \\
\text { Patient }\end{array}$ & $\begin{array}{l}\text { Idade } \\
\text { Age }\end{array}$ & $\begin{array}{l}\text { Sexo } \\
\text { Sex }\end{array}$ & $\begin{array}{l}\text { Cor } \\
\text { Color }\end{array}$ & $\begin{array}{l}\text { Indicação } \\
\text { Indication }\end{array}$ & $\begin{array}{l}\text { Local } \\
\text { Local }\end{array}$ & $\begin{array}{l}\text { Amaciantes } \\
\text { Softener }\end{array}$ & $\begin{array}{l}\text { Histopatológico } \\
\text { Histopathology }\end{array}$ \\
\hline 01 & 60 & $\mathrm{~F}$ & $\mathrm{~B} / W$ & $\begin{array}{l}\text { Onicólise e hiperceratose } \\
\text { subungueal, Onicomicose? } \\
\text { Onycholysis and subungual } \\
\text { hyperkeratosis Onychomycosis? }\end{array}$ & $\begin{array}{l}\text { Hálux esquerdo - leito punch } 04 \\
\text { Left hallux - bed Punch } 04\end{array}$ & Koh $20 \% 15^{\prime} 56^{\circ} \mathrm{c}$ & $\begin{array}{l}\text { Pas negativo; sugestivo de Onicopatia } \\
\text { traumática / Pas negative; suggestive of } \\
\text { traumatic onychopathy }\end{array}$ \\
\hline 02 & 68 & M & $\mathrm{B} / W$ & $\begin{array}{l}\text { Onicólise e hiperceratose } \\
\text { subungueal, Onicomicose? } \\
\text { Onycholysis and subungual } \\
\text { hyperkeratosis Onychomycosis? }\end{array}$ & $\begin{array}{l}\text { Hálux esquerdo - leito Fuso } \\
\text { longitudinal / Left hallux - bed } \\
\text { Longitudinal strip }\end{array}$ & Tween 40 & $\begin{array}{l}\text { Inadequado para diagnóstico } \\
\text { Inadequate for diagnosis }\end{array}$ \\
\hline 03 & 5 & $\mathrm{~F}$ & $\mathrm{~B} / W$ & $\begin{array}{l}20 \text { unhas ásperas, Traquioníquia? } \\
20 \text { rough nails Trachyonychia? }\end{array}$ & $\begin{array}{l}\text { Hálux diereito - leito Punch } 04 \\
\text { Right hallux - bed Punch } 04\end{array}$ & Tween 40 & $\begin{array}{l}\text { Traquioníquia espongiótica (Fig.1) } \\
\text { Spongiotic trachyonychia (fig. 1) }\end{array}$ \\
\hline $04 \mathrm{~A}$ & 28 & M & $\mathrm{B} / W$ & $\begin{array}{l}\text { Eritema e onicólise em faixa } \\
\text { longitudinal /Erythema and ony- } \\
\text { cholysis em longitudinal band }\end{array}$ & $\begin{array}{l}\text { Polegar esquerdo - matriz } \\
\text { Punch } 03 \text { / Left thumb - matrix } \\
\text { Punch } 03\end{array}$ & - & $\begin{array}{l}\text { Líquen plano ungueal } \\
\text { Ungual lichen planus }\end{array}$ \\
\hline $04 \mathrm{~B}$ & 28 & M & $\mathrm{B} / W$ & $\begin{array}{l}\text { Pterígio ungueal (Fig. 2) } \\
\text { Ungual pterygium (Fig. 2) }\end{array}$ & $\begin{array}{l}\text { Hálux esquerdo - leito Punch } 04 \\
\text { Left hallux - bed Punch } 04\end{array}$ & Tween 40 & $\begin{array}{l}\text { Líquen plano ungueal (Fig. 3) } \\
\text { Ungual lichen planus (fig. 3) }\end{array}$ \\
\hline 05 & 37 & $\mathrm{~F}$ & $\mathrm{~B} / W$ & $\begin{array}{l}\text { Melanoníquia estriada } \\
\text { Striated melanonychia }\end{array}$ & $\begin{array}{l}\text { Polegar esquerdo - matriz } \\
\text { Punch } 03 \text { / Left thumb - matrix } \\
\text { Punch } 03\end{array}$ & - & $\begin{array}{l}\text { Hiperplasia melanocítica benigna (Fig. 4) } \\
\text { Hiperplasia melanocítica benigna (Fig. 4) }\end{array}$ \\
\hline 06 & 64 & $\mathrm{~F}$ & $\mathrm{P} / B$ & $\begin{array}{l}\text { Lesão verrucosa prega lateral, } \\
\text { Verruga vulgar? } \\
\text { Verrucose lesion lateral fold } \\
\text { Common wart? }\end{array}$ & $\begin{array}{l}4^{\circ} \text { Dedo mão d - leito Fuso } \\
\text { longitudinal / 4th finger, right } \\
\text { hand - bed Longitudinal strip }\end{array}$ & Koh $20 \% 15,56^{\circ} \mathrm{c}$ & $\begin{array}{l}\text { Onicomicose + Contaminaçâo bacteri- } \\
\text { ana (Fig. 5) / Onychomycosis + bacter- } \\
\text { ial contamination (fig. 5) }\end{array}$ \\
\hline 07 & 34 & $\mathrm{~F}$ & $\mathrm{~B} / W$ & $\begin{array}{l}\text { Onicólise e hiperceratose } \\
\text { subungueal, Onicomicose? } \\
\text { Onycholysis and subungual } \\
\text { hyperkeratosis Onychomycosis? }\end{array}$ & $\begin{array}{l}\text { Hálux esquerdo - leito punch } 04 \\
\text { Left hallux - bed punch } 04\end{array}$ & Koh $20 \% 15^{\prime} 56^{\circ} \mathrm{c}$ & $\begin{array}{l}\text { Inadequado para diagnóstico } \\
\text { Inadequate for diagnosis }\end{array}$ \\
\hline 08 & 30 & $\mathrm{~F}$ & $\mathrm{~B} / W$ & Coiloníquia / Koilonychia & $\begin{array}{l}\text { Hálux diereito - leito - Punch } 04 \\
\text { Right hallux - bed Punch } 04\end{array}$ & Tween 40 & $\begin{array}{l}\text { Sugestivo da ausência da porção super- } \\
\text { ficial da lâmina ungueal por provável } \\
\text { interrupção da produção pela matriz } \\
\text { proximal / Suggestive of absence of } \\
\text { superficial portion nail plate, probably } \\
\text { due to interruption of production by } \\
\text { proximal matrix }\end{array}$ \\
\hline 09 & 30 & $\mathrm{~F}$ & $\mathrm{P} / B$ & $\begin{array}{l}\text { Tumor pigmentado na prega } \\
\text { proximal / Pigmented tumor in } \\
\text { proximal fold }\end{array}$ & $\begin{array}{l}\text { Polegar d - prega proximal - } \\
\text { incisional / Right thumb - proxi- } \\
\text { mal fold - incisional }\end{array}$ & - & $\begin{array}{l}\text { Nevo melanocítico combinado, tipo } \\
\text { intradérmico / Combined melanocytic } \\
\text { nevus, intradermal type }\end{array}$ \\
\hline 10 & 10 & M & $\mathrm{B} / W$ & $\begin{array}{l}\text { Unhas ásperas, Psoríase } \\
\text { Rough nails Psoriasis }\end{array}$ & $\begin{array}{l}4^{\circ} \text { dedo mão e - leito - Punch } 04 \\
\text { Right thumb - proximal fold - } \\
\text { incisional }\end{array}$ & - & $\begin{array}{l}\text { Psoríase + Liquenificação do leito } \\
\text { ungueal (Fig. 6) / Psoriasis + lichenifi- } \\
\text { cation of ungual bed (fig. } 6 \text { ) }\end{array}$ \\
\hline 11 & 47 & $\mathrm{~F}$ & $\mathrm{~B} / W$ & $\begin{array}{l}\text { Onicólise distal } 20 \text { anos de } \\
\text { evolução, Psoríase? } \\
\text { Distal onycholysis with } 20 \\
\text { years duration Psoriasis? }\end{array}$ & $\begin{array}{l}\text { Hálux esquerdo - leito punch } 04 \\
\text { Left hallux - bed punch } 04\end{array}$ & Koh $20 \% 15^{\prime} 56^{\circ} \mathrm{c}$ & $\begin{array}{l}\text { Onicólise de provável natureza } \\
\text { traumática / Onycholysis, probably of } \\
\text { traumatic nature }\end{array}$ \\
\hline
\end{tabular}

Os critérios de inclusão utilizados foram:

- presença de melanoníquia longitudinal,

- presença de tumores da unidade ungueal,

- suspeita de processo infeccioso da unidade ungueal no qual testes para pesquisa de fungos tenham sido negativos, of nail lesions.

The inclusion criteria were:

- presence of longitudinal melanonychia;

- presence of tumors in the nail unit;

- suspicion of infectious process in the nail unit in which 
- presença de condições dermatológicas inflamatórias, com acometimento ungueal exclusivo.

Foram excluídos:

- pacientes que se recusaram a realizar a biópsia,

- pacientes com distúrbios psiquiátricos que inviabilizassem a realização do procedimento,

- pacientes com história de doença vascular periférica,

- processo infeccioso agudo do aparelho ungueal,

- discrasia sangüínea.

As biópsias foram realizadas na sala de cirurgia dermatológica.

A anti-sepsia de mãos ou pés foi realizada com povidine degermante e solução de álcool e éter.

$\mathrm{Na}$ anestesia loco-regional, utilizou-se lidocaína a $2 \%$, sem adrenalina. Nas biópsias da matriz, foi adotada anestesia troncular. Nos casos de biópsia do leito, empregou-se anestesia local na junção da prega proximal e lateral, progredindo até a ponta do dedo, conforme descrito por Scher, em 1978. ${ }^{11}$ Nas biópsias do leito, não foi feito garroteamento, imprescindível, no entanto, nas da matriz.

Na biópsia do leito, recorreu-se a punch não descartável de $4 \mathrm{~mm}$ e na da matriz, a punch descartável de $3 \mathrm{~mm}$. $\mathrm{O}$ acesso à matriz foi realizado por incisões laterais na prega ungueal proximal e reparo. Nas biópsias dos elementos periungueais, os autores seguiram as orientações gerais para biópsia da pele.

A indicação de biópsia da matriz decorreu da presença de melanoníquia estriada e da suspeita de doenças ungueais originadas na matriz. As biópsias do leito foram realizadas nas doenças inflamatórias com acometimento da matriz e do leito e serviram para confirmar suspeita de infecção quando os exames micológicos haviam sido negativos. As biópsias do tecido periungueal foram usadas para diagnosticar lesão tumoral.

O curativo utilizado foi oclusivo e compressivo, trocado nas primeiras 48 horas e, a seguir, diariamente.

O fragmento de biópsia foi submetido ao preparo com $\mathrm{KOH}$ a $20 \%$ a $56^{\circ} \mathrm{C}$ por 30 minutos, posteriormente à fixação do material em formol ou à imersão em solução aquosa a $10 \%$ de Tween 40 por 24 horas previamente à fixação em formol.

A seguir, encaminhou-se o material ao setor de Anatomia Patológica da Faculdade de Medicina da Universidade do Estado do Rio de Janeiro, onde foi incluído em parafina, cortado com espessura de $5 \mu$ e corado pela hematoxilina-eosina e pelo ácido periódico de Schiff (PAS).

A avaliação histopatológica foi realizada no setor de Dermatopatologia do Hospital Universitário Pedro Ernesto - UERJ.

\section{RESULTADOS}

Realizaram-se 12 biópsias ungueais em 11 pacientes, duas incisionais e 10 por punch, cujos resultados estão relatados na tabela 1 . tests for isolation of fungi were negative;

- presence of inflammatory dermatological conditions with exclusive nail involvement.

The exclusion criteria were:

- patients that refused to undergo biopsy;

- patients with psychiatric disturbances that rendered the procedure unfeasible;

- patients with a history of peripheral vascular disease;

- acute infectious process of the nail unit,

- blood dyscrasia.

The biopsies were performed in the dermatological surgery theater.

Antisepsis of the hands or feet was done with povidone iodine (PVPI) and a solution of alcohol and ether.

The local-regional anesthetic used was $2 \%$ lidocaine without adrenaline, while in the biopsies of the matrix, nerve block anesthetics was used. In the cases of biopsy of the bed, local anesthetics were used in the junction of the proximal and lateral fold, progressing to the fingertip, as described by Scher, in 1978. " A clipping was not used for biopsies of the nail bed, though this was essential for matrix biopsies.

Disposable punches of $4 \mathrm{~mm}$ and $3 \mathrm{~mm}$ were used for biopsies of the bed and matrix, respectively. Access to the matrix was achieved by lateral incisions in the proximal nail fold and repair. In the biopsies of the periungual elements, the authors followed the general orientations for biopsy of the skin.

Indication for biopsy of the matrix was considered to be the presence of striated melanonychia and suspicion of nail diseases originating in the matrix. Biopsies of the nail bed were performed for inflammatory diseases with involvement of the matrix and bed and were used to confirm suspicion of infection when the mycological exams were negative. Biopsies of the periungual tissue were used to diagnose tumoral lesion.

Occlusive and compressive dressings were used and these were changed after the first 48 hours and then on a daily basis.

The biopsy fragment was submitted to a preparation of $20 \% \mathrm{KOH}$ at $56^{\circ} \mathrm{C}$ for 30 minutes and then to fixing of the material in formol or immersion in $10 \%$ aqueous solution of Tween 40 for 24 hours prior to fixing in formol.

The material was then forwarded to the Pathological Anatomy Department of the Medicine School of the University of the State of Rio de Janeiro, where it was embedded in paraffin, cut into $5 \mu$ sections and stained with hematoxylin and eosin and with periodic-acid Schiff (PAS).

The histopathological evaluation was performed by the Dermatopathology Department of the HUPE-UERJ.

\section{RESULTS}

A total of 12 nail biopsies were performed in 11 patients, of which two were incision and 10 punch biopsies, the results are summarized in table 1. 


\section{DISCUSSÃO}

$\mathrm{Na}$ realização das biópsias, os autores se depararam com algumas dificuldades. Nas unhas que apresentavam onicólise e espessamento da lâmina ungueal, houve, em $100 \%$ dos casos, descolamento da lâmina do leito durante o procedimento, levando à necessidade de emblocamento separado da lâmina e do leito biopsiado.

Com relação a biópsias de leito, em $1995^{17}$ Souza utilizou o punch de três ou 4mm; Rich, ${ }^{12}$ em 1992, mostrou a técnica de duplo punch; orientando a utilização de um punch de $4 \mathrm{~mm}$ para retirada da lâmina ungueal e um de $3 \mathrm{~mm}$ para a retirada do fragmento do leito; nas aqui relatadas, houve grande dificuldade técnica no emprego do punch descartável, pois a lâmina ungueal desprendida durante a biópsia a ele aderia internamente, o que não aconteceu quando usado o punch não descartável.

Nas biópsias da matriz, a orientação indica escolha de punch de $3 \mathrm{~mm}$ ou fuso transversal, acompanhando a curvatura da lúnula e evitando a matriz proximal, se possível. ${ }^{15,16}$

Dado que nesse tipo de biópsia a exposição da matriz pela confecção de retalho da prega proximal é indispensável, os autores escolheram o punch descartável de $3 \mathrm{~mm}$, na tentativa de prevenir seqüelas definitivas na unha.

Com relação à anestesia, eles julgam ser fundamental, nos casos de biópsia da matriz, a anestesia troncular, já que é necessário campo cirúrgico sem sangue, o que facilita identificar o local da alteração na matriz, orientando a biópsia. Quando se tratava de biopsiar leito, aplicaram anestesia local, e houve boa tolerância por parte dos pacientes, bem como efetividade de bloqueio. Não utilizaram garrote, o sangramento foi mínimo e em nada prejudicou o procedimento.

Outro fator decisivo na precisa avaliação histológica da biópsia é a orientação do material obtido. Trata-se normalmente de pequenos fragmentos, e a orientação inadequada pode comprometer o resultado. É possível a utilização de corantes nessa orientação ou a marcação da peça com uma pequena incisão lateral, definindo se a inclusão será transversal ou longitudinal. Não se aconselha a imediata clivagem do material como forma de orientar a inclusão, pelo risco de prejuízo ao exame histopatológico.

Em $1997^{6}$ Jerasutus mostrou, com detalhes, as alterações histopatológicas do leito ungueal quando de inclusão transversal: os cones epidérmicos são estreitos e longos, intercalados por papilas dérmicas, formando pregas longitudinais regulares ao longo do leito ungueal. Sugere-se, portanto, a inclusão longitudinal.

Os pacientes foram acompanhados pelos autores, que não observaram seqüelas naqueles submetidos à biópsia do leito. Os dois pacientes submetidos à biópsia da matriz foram acompanhados até o crescimento normal e completo da lâmina ungueal, sem sulcos ou onicólise, o que foi interpretado como resultado final sem seqüelas. A casuística dos autores é pequena e pode não representar a real incidência de complicações.

\section{DISCUSSION}

While performing the biopsies, the authors encountered several difficulties. In 100\% of the cases in which the nails presented onycholysis and thickening of the nail plate, there was a separation between nail plate and nail bed during the procedure, leading to the need for nail plate and nail bed to be mounted separately.

Regarding biopsies of the bed, in $1995^{17}$ Souza used a 3 or 4mm punch; Rich, ${ }^{12}$ (1992) described a technique using two punches; recommending the use of a $4 \mathrm{~mm}$ punch for sampling the nail plate followed by a $3 \mathrm{~mm}$ punch for removal of a fragment of the nail bed; in the cases reported in the present work, there was great technical difficulty in the use of disposable punches, because the nail plate loosened during the biopsy and became adhered to the internal part of the punch, which did not happen when non disposable punches were used.

In biopsies of the matrix, the choice of a $3 \mathrm{~mm}$ punch or transversal strip, is recommended and accompanying the curvature of the lunula while avoiding the proximal matrix, whenever possible. ${ }^{15,16}$

Given that in this type of biopsy, exposure of the matrix for preparing a specimen of the proximal fold is indispensable, the authors opted for a disposable $3 \mathrm{~mm}$ punch, with a view to preventing definitive sequels in the nail.

Regarding anesthesia, a nerve block is considered fundamental as the anesthetic procedure in the cases of biopsy of the matrix, since a surgical field free from blood is necessary to facilitate identification of the site in the matrix that presents alterations and thereby guiding the biopsy. When performing a biopsy in the nail bed, local anesthesia was applied and there was good tolerance on the part of the patients, as well as effectiveness of the blockade. It was not necessary to use clipping since the bleeding was minimal and it did not affect the procedure.

Another decisive factor for a precise histological evaluation of the biopsy is the orientation of the material obtained. This usually involves small fragments and an incorrect orientation can invalidate the results. To indicate the orientation one can use colors or mark the specimen with a small lateral incision to define whether the inclusion was transversal or longitudinal. The immediate cleaving of the material as a means to guide the inclusion is not advisable as there is a risk that this might alter the histopathological exam.

In 1997, ${ }^{6}$ Jerasutus demonstrated in detail the histopathological alterations to the nail bed following a transverse inclusion: the epidermal cones are narrow and long, inserted by dermal papillae, forming regular longitudinal folds along the nail bed. Therefore a longitudinal inclusion is recommended.

The patients were followed-up by the authors and no sequela were observed among those submitted to biopsy of the nail bed. The two patients submitted to biopsy of the matrix were followed-up until normal and complete growth of the nail bed, without furrows or onycholysis, which was 
Com relação ao processamento, as biópsias da matriz e tecidos periungueais foram diretamente fixadas em formol, o que não comprometeu nem a inclusão, nem a avaliação histopatológica dos materiais.

As biópsias do leito foram submetidas a dois modos de amaciamento, utilizando $\mathrm{KOH}$ a $20 \%$, aquecido a $56^{\circ} \mathrm{C}$ por 15 minutos, ou solução aquosa a $10 \%$ de Tween 40 . Com relação ao corte do material no micrótomo, a dificuldade se relacionava em maior ou menor grau com a espessura da lâmina ungueal, já esperada e contornada pela utilização de lâminas novas no micrótomo a cada quatro diferentes materiais processados.

Na avaliação histopatológica não se observou prejuízo citológico nem histológico nas amostras. Ambas as técnicas são de fácil reprodução e baixo custo.

Não foi possível realizar a análise estatística do grupo, dadas sua pequena dimensão e falta de homogeneidade. Houve troca constante das lâminas do micrótomo, para facilitar os cortes, o que interferiu na avaliação da eficácia das técnicas de amaciamento.

Com relação aos resultados obtidos pelo exame histopatológico:

- os casos suspeitos clinicamente de onicomicose que tiveram exames micológicos negativos não foram confirmados pela histopatologia. O número de casos é pequeno (três), o que não permite aos autores tirar conclusões. Eles evitaram, porém, tratamentos onerosos e com efeitos colaterais. Acreditam tratar-se de onicopatia traumática - que freqüentemente acomete o hálux, local das biópsias aqui focalizadas -, podendo apresentar-se clinicamente como onicólise ou hiperceratose reativa, ${ }^{25}$

- em um dos casos clínicos, a suspeita era de verruga subungueal, e, durante a histopatologia, não foram encontradas características histológicas de infecção pelo HPV, sendo os autores surpreendidos por hifas na coloração pelo PAS. Infelizmente, não havia sido feito exame micológico prévio. Pode-se inferir aqui a importância da realização da coloração para pesquisa de fungos nas biópsias de unha, sobretudo nos casos com hiperceratose ungueal;

- no caso de melanoníquia estriada, a importância está no fato de se excluir, com segurança, a malignidade, o que é igualmente válido para o caso de tumor periungueal, também biopsiado;

- no caso da criança com traquioníquia, os achados histológicos na biópsia do leito apenas foram secundários às alterações primárias que ocorriam na matriz. $\mathrm{O}$ melhor teria sido biopsiar a matriz;

- em outro caso, com características clínicas de psoríase, a biópsia do leito foi suficiente para se concluir o diagnóstico. - no caso de líquen plano, já que a doença acomete tanto a matriz quanto o leito, preferiu-se biopsiar o leito. Quando a lesão é muito inicial e exclusiva da matriz, como em um dos casos biopsiados, a única forma de conseguir o diagnóstico é pela biópsia da matriz. considered a final result without sequela. However, the authors' patient sample was small and consequently may not be representative of the real incidence of complications.

Regarding the processing, the biopsies of the matrix and periungual tissue were fixed directly in formol, which did not alter the inclusion or histopathological evaluation.

Biopsies of the bed were submitted to one of two methods of softening, using either $20 \% \mathrm{KOH}$, heated to $56^{\circ} \mathrm{C}$ for 15 minutes, or $10 \%$ aqueous solution of Tween 40 . Regarding the sectioning of the material in the microtome, the difficulty was linked to the greater or lesser degree of thickening of the nail plate, as was already expected and overcome by the use of new blades in the microtome after every four different specimens processed.

In the histopathological evaluation, no cytological or histological damage was observed in the samples. Both techniques are easily reproduced and have a low cost.

It was not possible to perform statistical analysis of the group given its limited number of samples and lack of homogeneity. The blades in the microtome were frequently changed to facilitate the sectioning, which also interfered in the evaluation of the effectiveness of the softening techniques.

As for the results obtained from the histopathological exam:

- the clinically suspected cases of onychomycosis that presented negative mycological exams were not confirmed by histopathology. The number of cases was small $(n=3)$, which did not allow the authors to reach any conclusions. However costly procedures with side effects were avoided. It was suspected that these were cases of traumatic onychopathy; which frequently affects the hallux, the site of the biopsies focused here and that can present clinically as onycholysis or reactive hyperkeratosis ${ }^{25}$

- in one of the clinical cases, subungual wart was suspected and the histopathology revealed no histological characteristics of infection by $H P V$, although the authors were surprised by hyphae in the staining by PAS. Unfortunately, no previous mycological exam had been done. This fact suggests how important it is to perform staining for the isolation of funghi in nail biopsies, above all in those cases with ungual hyperkeratosis;

- in the case of striated melanonychia, it is important to exclude, with certainty, the possibility of malignancy, which was equally valid for the case of periungual tumor that was also biopsied;

- in the case of the child with trachyonychia, the histological findings in the biopsy of the bed were only secondary to the primary alterations occurring in the matrix. Hence it would have been better to perform a biopsy in the matrix; - in the case with clinical characteristics of psoriasis, biopsy of the nail bed was sufficient to confirm the diagnosis. - in the case of lichen planus, since the disease affects both the nail matrix and bed, biopsy of the bed was preferred. However, when the lesion is in the very initial stage and restricted to the matrix, as in one of the biopsy cases, a biopsy 
Nos casos suspeitos de onicomicose, cujos exames micológicos foram negativos ou quando se deseja excluir psoríase, um método disponível e que não deve ser esquecido, intermediário entre o exame micológico e a biópsia ungueal, é o exame histopatológico de fragmentos de lâmina ungueal. Suarez, em $1991,{ }^{25}$ mostrou sua utilidade em diagnosticar onicomicose, nos casos de exame micológico negativo para fungos. Machler, em $1998,{ }^{20} \mathrm{e}$ Grammer-West, em $1998,{ }^{21}$ lidando com casos de onicodistrofia, endossaram essa utilidade para o diagnóstico de onicomicose e psoríase.

\section{CONCLUSÕES}

A biópsia ungueal requer, do dermatologista, amplo conhecimento da anatomia da unidade da unha, sendo imprescindíveis desde a escolha do local até a orientação da inclusão e interpretação dos resultados.

Os locais adequados de biópsia no aparelho ungueal para as diferentes doenças da unha são:

- melanoníquia estriada ou tumores na matriz: matriz;

- distrofia ungueal envolvendo toda a extensão da lâmina: matriz;

- massa ou tumor no leito: leito;

- unha psoriásica ou fúngica questionável ou não documentada: leito;

- onicólise inexplicada: leito;

- hiperceratose subungueal: leito;

- lesão vegetante e pigmentação subungueal inexplicada: leito;

- paroníquia crônica, tumores ou massas da prega ungueal causando distrofia ungueal: prega ungueal.

Nas biópsias ungueais não houve diferença na dificuldade técnica de incluir ou cortar o material consoante o método de amaciamento empregado.

Não houve prejuízo citológico nem histológico das biópsias com as duas técnicas de amaciamento da lâmina ungueal utilizadas.

A biópsia ungueal é procedimento seguro que pode ajudar no diagnóstico das doenças da unha.

Pode-se sugerir uma rotina para a biópsia ungueal:

1) local: guiar-se pela alteração ungueal presente;

2) anestesia: regional para as biópsias da matriz e local para as do leito;

3) utilização de garrote para biópsia da matriz o que é dispensável nas do leito;

4) punch: descartável de $3 \mathrm{~mm}$ nas biópsias da matriz e não descartável de 4mm nas biópsias do leito;

5) marcar o fragmento biopsiado com corantes ou cortar uma de suas laterais, orientando assim a inclusão: transversal ou longitudinal;

6) fixação: diretamente em formol nas biópsias da matriz e utilização de técnicas de amaciamento, tanto Tween 40 em solução aquosa a $10 \%$ quanto $\mathrm{KOH}$ a $20 \%$, por 15 minutos, a $56^{\circ} \mathrm{C}$, nas biópsias de leito. of the matrix is essential.

In the cases of suspected onychomycosis, in which the mycological exams were negative or whenever it was necessary to exclude psoriasis, the histopathological exam of nail plate fragments, midway should not be neglected. Suarez (1991) $)^{25}$ demonstrated its usefulness for diagnosing onychomycosis in the cases of negative mycological exam for fungi. Machler in 1998, ${ }^{20}$ and Grammer-West 1998, ${ }^{21}$ working with cases of onychodystrophy, endorsed its usefulness for the diagnosis of onychomycosis and psoriasis.

\section{CONCLUSIONS}

Nail biopsy should only be carried out by dermatologists who have a broad knowledge of the anatomy of the nail unit, which is indispensable in all aspects ranging from choice of the site to orientation of the inclusion and interpretation of the results.

The appropriate sites for biopsy in the ungual apparatus for the various diseases of the nail are:

- striated melanonychia or tumors in the matrix: matrix;

- ungual dystrophy involving the entire extension of the nail plate: matrix;

- mass or tumor in the nail bed: bed;

- doubtful or non documented psoriatic or fungous nail: bed;

- unexplained onycholysis: bed;

- subungual hyperkeratosis: bed;

- vegetative lesion and unexplained subungual pigmentation: bed;

- chronic paronychia, tumors or masses of the ungual fold causing ungual dystrophy: ungual fold.

In the nail biopsies there was no difference in the technical difficulty of including or sectioning the material relative to the softening the method used.

There was no cytological or histological damage to the biopsies with either of the two techniques used for softening the nail plate.

Nail biopsy is safe a procedure that can help in the diagnosis of ungual diseases.

A routine for nail biopsy is suggested below:

1) site: use the nail alteration presented as a guideline;

2) anesthesia: regional for biopsies of the matrix and local for the nail bed;

3) clipping should be used for biopsy of the matrix and is dispensable for those of the nail bed;

4) punch: use a disposable 3 mm punch for biopsies of the matrix and a non disposable 4mm punch for biopsies of the nail bed;

5) mark the biopsy specimen with colors or trim one of its sides, in order to guide the inclusion: transversal or longitudinal; 6) fixing: directly in formol for biopsies of the matrix and the use softening techniques is advised, either $10 \%$ Tween 40 in aqueous solution or $20 \% \mathrm{KOH}$ for 15 minutes at $56^{\circ} \mathrm{C}$ for biopsies of the nail bed. 


\section{AGRADECIMENTOS}

Ao Dr. Ivan Curtiss Silviano Brandão pela revisão técnica do texto em inglês.

\section{REFERÊNCIAS/ REFERENCES}

1. Gardner E, Gray DJ, O'Rahilly R. Anatomia Estudo Regional do Corpo Humano. $4^{\text {a }}$ ed. Rio de Janeiro: Guanabara Koogan, 1978:52-53.

2. González-Serva A. Structure and Function. In: Scher RK, Daniel III CR. Nails Therapy-Diagnosis-Surgery. 2nd. ed. Philadelphia: WB Saunders Company, 1997:12-31.

3. Baran R, Dawber RPR, Tosti A, Haneke E. A Text Atlas of Nail Disorders - Diagnosis and Treatment. London: Mosby, 1996.

4. Griffin TD. Inflamatory Diseases of the Nail. In: Lever's Histopathology of the Skin, $8^{\text {a }}$ ed., Philadelphia: David Elder et al. Lippincott Raven Publishers, 1997:423-428.

5. Omura EO. Histopathology of the Nail. Dermatologic Clinics, 1985;3(3):531-541.

6. Jerasutus S. Histology and Histopathology. In: Scher RK, DANIEL III, CR. Nails Therapy-Diagnosis-Surgery. 2nd ed. Philadelphia: WB Saunders Company, 1997. p.55-100.

7. Tosti A, Piraccini BM. Biology of Nails. In Fitzpatrick's. Dermatology in General Medicine, 5th Ed. Mc Graw-Hill, 1999:239-244.

8. Zaias N, Alvarez J. The Formation of the Primate Nail Plate. An Auto-radiographic Study in Squirrel Monkey. J Invest Dermatol 1968;51:120-37.

9. Johnson M, Comaish JS, Shuster, S. Nail is produced by the normal nail bed: a controversy resolved. British Journal of Dermatology. 1991;125:27-29.

10. Stone OJ, Barr RJ, Herten RJ. Biopsy of the Nail Area. Cutis. 1978(21):257-260.

11. Scher RK. Punch Biopsies do Nails. A Simple, Valuable Procedure. J Dermatol Surg Oncol. 1978;4(7):528-530.

12. Rich P: Nail Biopsy: Indications and Methods. J Dermatol Surg Oncol, 1992;18:673-682

13. Zaias N. The Longitudinal Nail Biopsy. J Investig Dermatol. 1967;49(4):406-408.

14. Scher RK. Longitudinal Resection of Nails for Purposes of Biopsy and Treatment. J. Dermatol Surg Oncol. 1980;6(10):805-807.

15. Salasche SJ. Surgery. In: Scher RK, DANIEL III CR. Nails Therapy-Diagnosis-Surgery. 2nd. ed. Philadelphia: WB Saunders Company, 1997:326-349.

16. Del Rosso JQ, Basuk PJ, Scher RK, Ricci AR. Dermatologic Diseases of the Nail Unit. In: Scher RK, DANIEL III CR. Nails

\section{ACKNOWLEDGEMENTS}

The authors would like to thank Dr. Ivan Curtiss Silviano Brandão for revising the english version of this paper.

Therapy-Diagnosis-Surgery. 2nd. ed. Philadelphia: WB Saunders Company, 1997:172-200.

17. Souza MCF, Corredor JG, Duque H, Mendonça IRM, Azulay RD. O valor da biópsia da unha para diagnóstico histopatológico da psoríase e do líquen plano ungueal. Dermatológica 1995:29-31. 18. Elewski BE. Diagnostic techniques for confirming onychomycosis. J Am Acad Dermatol. 1996;35(3):S6-S9.

19. Blecher P, Korting HC. A new combined diagnostic approach to clinically and microscopically suspected onychomycosis unproven by culture. Mycoses. 1993;36:321-324.

20. Macher BC, Kirsner RS, Elgart GW. Routine Histologic Examination for the Diagnosis of Onychomycosis: an Evaluation of Sensitivity and Specificity. Cutis, 1998;61:217-219.

21. Grammer-West NY, Corvette DM, Giandoni MB, Fitzpatrick JE. Clinical Pearl: Nail plate biopsy for the diagnosis of psoriatic nails. J Am Acad Dermatol. 1998;38(2):260-262.

22. Alvarez R, Zaias N. A modifield polyethylene glycol-pyroxylin embedding method specially suited for nails. J Invest Dermatol, 1967;49:409-410.

23. Lewin K, De Wit AS, Lawson R. Softening Techniques for Nails Biopsies. Arch Dermatol 1973;107:223-224.

24. Pierard GE, Arrese JE, Pierre $S$ et al. Diagnostic Microscopique des Onychomycoses. Ann Dermatol Venerol. 1994;121:25-29.

25. Haneke E, Baran R. Nail Surgery and Traumatic Abnormalities. In Baran R, Dawber RPR. Diseases of the Nails and their Management. 2nd Ed. Cambridge:Blackwell Science, 1995:345-415.

26. Suarez SM, Silvers DN, Scher RK. Histologic Evaluation of Nail Clippings for Diagnosing Onychomycosis. Arch Dermatol 1991;127:1517-19.

ENDEREÇO PARA CORRESPONDÊNCIA: / MAILING ADDRESS:
Geraldo Magela Magalhães
Avenida do Contorno, 4747 sala 906
Belo Horizonte MG $11050-060$
Tel/Fax: (31) 3281-2030
E-mail: germagela @ig.com.br

